\title{
The Impact of Fiscal Policy on Income Inequality: A Case Study of Pakistan
}

\section{Suhrab Khan* and Ihtsham ul Haq Padda**}

\begin{abstract}
This study investigates the impact of various fiscal policy instruments on the income inequality of Pakistan using an Auto Regressive Distributed Lag (ARDL) model on annual data. We find that direct taxes reduce income inequality, measured using the Gini index, while indirect taxes increase disparities. As the major portion of tax revenues are indirect taxes, the current tax regime of Pakistan does not achieve income redistribution. Similarly, development expenditures have significantly reduced income inequality, likely through the creation of employment opportunities. On the other hand, the overall fiscal deficit increases income inequality, due to a rising public debt financed by (regressive) indirect taxes. This study suggests that in the case of Pakistan, where direct taxes are low, a large shadow economy exists, and weak tax administration prevails, an increase in development expenditures and broadening of the tax base of direct taxes should be the main fiscal policy tools for income redistribution. Moreover, persistent high fiscal deficits in the long run should be avoided. Finally, governments should reduce educational inequalities and promote democratic values in the country in order to promote greater fairness in distribution of income.
\end{abstract}

Keywords: Fiscal policy, Gini index, taxes, development expenditures, ARDL, Pakistan.

\section{JEL Classification: E62, H27, D63.}

\section{Introduction}

Fiscal policy plays a pivotal role in income redistribution. It has three main objectives: to support macroeconomic stability, provide public goods in the case of market failure, and redistribute income in the face of large and persistent inequality. Both tools of fiscal policy, i.e. tax and expenditure policies, affect the income distribution in the short as well as

\footnotetext{
${ }^{*}$ PhD Scholar, Department of Economics, Federal Urdu University of Arts Science and Technology (FUUAST), Islamabad, Pakistan.

** Assistant Professor, Department of Economics, Federal Urdu University of Arts Science and Technology (FUUAST), Pakistan.
} 
the long run. Taxation affects the behavior of consumers and firms by altering labor supply, consumption, and investment decisions, with the potential for reducing inequality in disposal income (Bakija, 2014; Chandoevwit \& Dahlby, 2007). Similarly, other expenditures such as education, infrastructure and other transfers also affect income inequality (Berg et al., 2018).

Recent empirical work shows that high income and wealth inequality retards economic growth mostly through the chanel of human capital. In modern growth theory, human capital is the main driver of economic growth. Large disparities in income lead to under-investment in human capital and increases in the fertility of the poor, thus negatively affecting the economic growth (de la Croix \& Doepke, 2003; Galor \& Moav, 2014). Income disparity is also a major cause of social injustice, with political unrest further slowing down economic growth as instability disincentivizes investment and economic activity (Alesina \& Perotti, 1996; Berg et al., 2018, Rodriguez, 2000). Inequality in income and opportunities also contributes to ethnic tension and social polarization, which not only discourages investment leading to resource misallocation but it also endangers property rights and enforcement of contracts (Gonzalez, 2007).

Developing countries like Pakistan face four major fiscal policy challenges: a low tax to GDP ratio, especially the contribution of direct taxes; high tax evasion and avoidance; weak tax institutions; and lastly, high government current expenditures (Padda, 2010; Padda 2014). Due to a low capacity for revenue generation, developing nations are constrained in their ability to increase the domestic revenues needed to finance social and physical infrastructure. At the same time, they are challenged to devise tax and expenditures policies that are economically efficient, minimize distortions, and fairly distribute the tax burden (Alavuotunki et al., 2017; Prichard et al., 2014).

Historically, Pakistan has been unable to sustain its periods of growth. This can be mostly attributed to high external inflows, imports and consumption-led spending rather than investment and export-led growth. The end result of these periods are rising debts and liabilities, as well as high fiscal and current account deficits that deplete foreign reserves and compel successive governments to approach the International Monetary Fund (IMF) for macroeconomic and financial stabilization. Figure 1 shows the fiscal deficit of Pakistan for the last decade. According to Pakistan Economic Survey 2019-20, total expenditures including development and nondevelopment are 21.2 percent of GDP while in the same year, total revenue 
including tax revenue plus non-tax revenues remained at about 15.3 percent of GDP. This revenue-expenditure gap is financed from both internal and external borrowing, which cause a fiscal situation that is unsustainable in the long run (Padda \& Akram, 2009). This high budget deficit coupled with current account deficits are the major cause of macroeconomic instability (Safdar \& Padda, 2017). Instead of relying on loans, the government should implement structural reforms to bridge the revenue-expenditure gap. Akram et al. (2007) estimate that Pakistan can raise the tax to GDP ratio from 12.2 percent to 36 percent through prudent tax policy and expenditure rationalization.

\section{Figure 1: Revenue-Expenditure Gap (\% of GDP)}

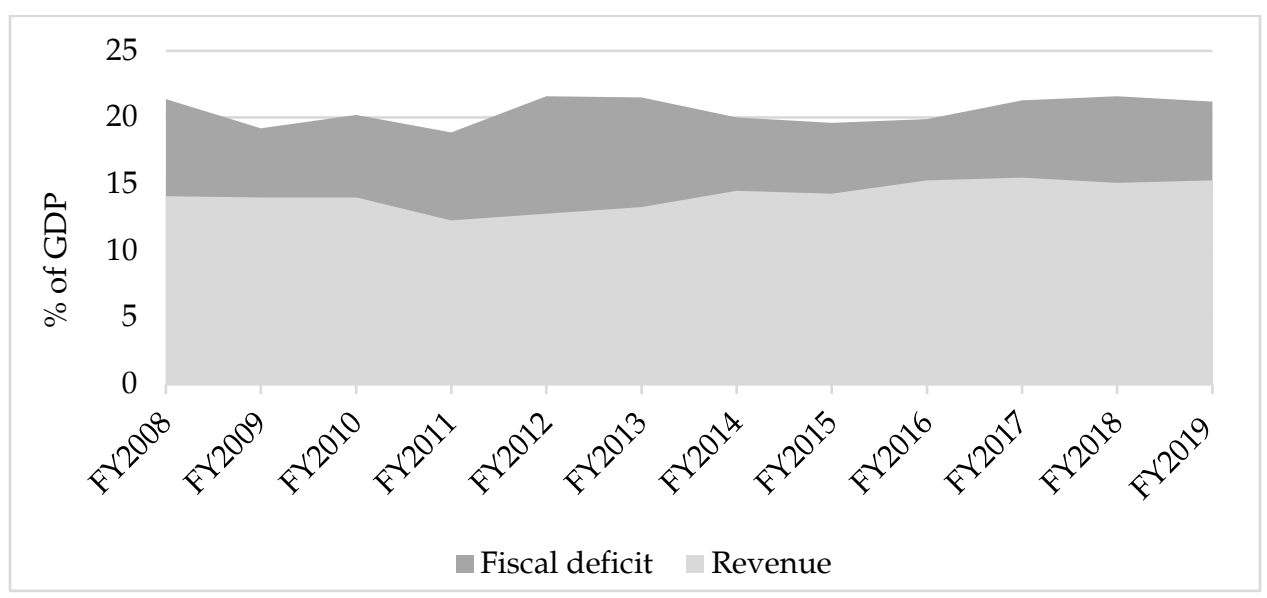

Source: Economic Survey of Pakistan, 2019-20.

In spite of high yet unproductive government expenditures, Pakistan's revenue mobilization experience is far below regional economies. It has a low tax to GDP ratio (11\%), a narrow tax base due to high exemptions and concessions, tax evasion, a large undocumented economy, and repeated tax amnesties, presenting a significant challenge to the much desired inclusive growth framework (Cevik, 2016). Moreover, institutional weaknesses, especially poorly trained tax officers, ambiguous tax laws and statutory regulatory orders (SROs), and culture undermine the tax potential of Pakistan (Martinez- Vazquez \& Cyan, 2015; Pasha, 2018). Within indirect taxes the sales tax, being the major contributor (63\%) to total FBR revenue, has become less efficient over the time. In 2010-11, sales tax collection efficiency, often called C-efficiency, had dropped to around 22.3 percent from 32.3 percent in 1990. Other regional countries such as Sri Lanka and the countries of Organization for Economic Co- 
operation and Development (OECD) have C-efficiency of 45 percent and 58 percent on average, respectively (Khan, 2015; Hassan \& Sarker, 2012).

A high concentration of indirect taxes as a revenue source has exacerbated income inequality in Pakistan (IMF, 2014). A recent study shows that the major portion of the tax burden of indirect taxes are borne by the low income households; according to Khan (2015) the poorest 10 percent of Pakistanis paid 9.3 percent of total indirect taxes while the richest 10 percent paid merely 5.9 percent. Moreover, the bulk of revenues are collected from the sales tax, excise tax, import tariff, etc. The incidence of indirect taxes is likely to land on the poor segment of the society as they tend to consume more of their income as tax as compared to higher income individuals (Martinez-Vazquez et al., 2012, Pasha, 2018).

Figure 2 shows the trend in inequality from the 1980 to 2019 and that the Gini index has been steadily rising, especially from 2007 onwards. The decline in the Gini index that occurred in the mid-eighties can be likely attributed to the inflow of foreign aid and removal of sanctions while the United States and other western countries helped Pakistan economically and militarily to oust the Soviet Union from Afghanistan (Sultana et al., 2014). After 2008, due to dwindling foreign aid, import and consumption led growth, and consistent fiscal deficits, every successive government in Pakistan has entered an IMF program after every successive government. IMF conditions such as abolishing subsidies, increasing tariffs on electricity, and imposition of goods and services tax (GST), badly affect low income people, resulting in increasing unemployment and inequality.

Figure 2: Trend in Gini Index 1980-2018

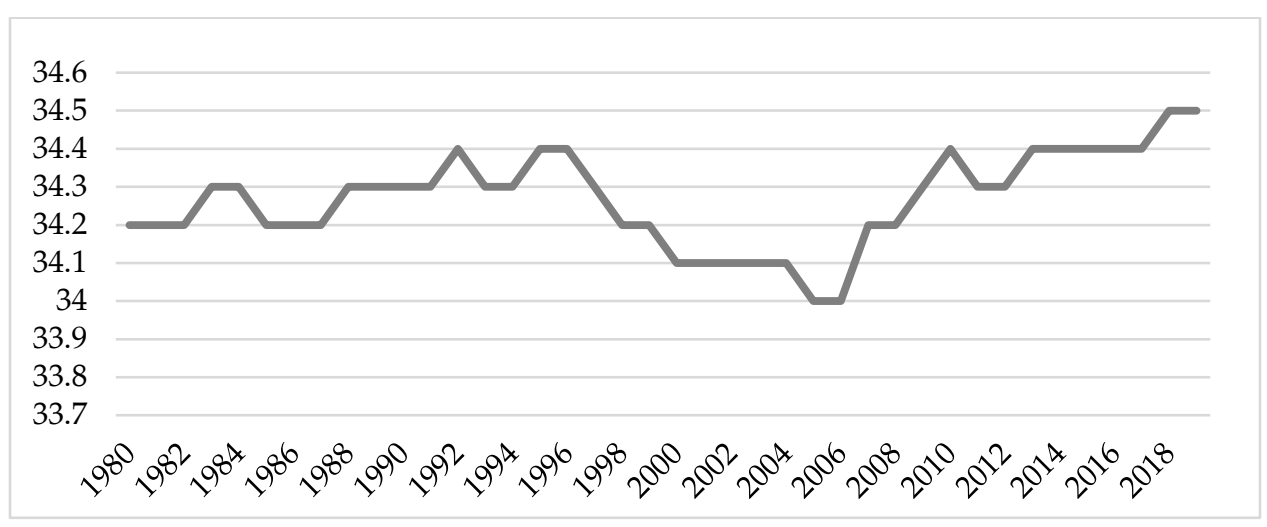


Keeping in view the vital role of fiscal policy in income redistribution, this study evaluates the impact of fiscal policy on income inequality in Pakistan. The short and long run impacts of direct taxes, indirect taxes, current expenditures, and development expenditures are explored using ARDL techniques. The next section discusses the relevant literature on fiscal policy and income inequality. Methodology and variable construction are discussed at the third section and the last section presents the results and some policy recommendations.

\section{Literature Review}

Tax policy and its potency to affect income inequality and resource reallocation has been debated since the early 1950s. At the outset taxation, especially progressive taxation, were assumed more effective in income redistribution and increasing the fiscal space for government outlays. Both the objectives of tax revenue and income distribution were thought to be achievable by imposing high effective tax rates on the personal income (Kaldor, 1963; Musgrave, 1959). With this backdrop, policymakers postWorld War II especially focused on taxation in promoting income and wealth distribution through high tax rates on the top income levels and on corporations. Very little attention was given to the negative impact of high tax rates on investment, savings, growth, and labor supply decisions of individuals and firms. The Heig-Simon concept of income, that is consumption plus change in the net wealth, became a best proxy of ability to pay (Bird \& Zolt, 2005; Cornia \& Martorano, 2012).

The 1970s recession led neoclassical economics to dominate in policy circles, ushering in economic and social policies that relied heavily on market forces and reducing the role of government. Both developed and developing economies drastically reduced the tax rate on the top incomes of both individuals and corporations (Piketty, 2015). These market-based policies and deregulation led to high income disparities worldwide. Due to sharp rises in income inequality, fiscal policy has come again into the limelight as an effective tool for redistribution (Piketty \& Goldhammer, 2013; Saez \& Zucman, 2016). Moreover, empirical studies also associated the unequal distribution of income with social injustice, political unrest, and a negative impact on growth as well as disruptive activities such as crimes, riots, etc. (Benabou, 1996; Rodriguez, 2012). Taxing economic elites leads to income redistribution, thus promoting democratic stability (Acemoglu \& Robinson, 2001; Karl, 2000). 
Government spending might help in ameliorating income disparities if its tax and transfer systems are redistributed in favor of the poor. Goñi et al. (2008) and Leubker (2012) confirm the income inequality reducing effects of government spending. Government spending and transfer payment helped in the reduction of income inequality (Frenette et al, 2009; Milligan, 2013). Causa and Hermansen (2017), using household level micro data from OECD countries, show that income inequality can be reduced by progressive taxes such as income and corporate taxes and by also increasing expenditures on social security and transfer payments. A prudent and sound fiscal policy can reduce income inequality and poverty. In the case of Pakistan, Bhatti et al. (2015) and Naqvi et al. (2011) also confirm that government transfer payments and especially taxes on agriculture income reduce income inequality and poverty. However, Papanek and Kyn (1986) show that taxation as policy tools will not have any significant impact on income distribution if government expenditures are directed toward the political, bureaucratic, and military elites rather than the social sectors that benefit the poor segments of society.

The empirical literature also demonstrates that direct taxes reduce income inequality. According to Hoeller et al. (2012), a country having a relatively small tax base and transfer system can attain the same level of income redistribution as compared to a country having a large tax base and transfer system if the former has a progressive, direct tax system. Similarly, Martinez- Vazquez and Sepulveda (2011) study the impact of direct taxes such as the personal income and corporate tax on the level of income inequality. This study suggests that in order to achieve an equal distribution of income, progressive and direct taxes should be introduced. Similarly, Maboshe and Woolard (2018) and Rossignolo (2017) examine the effect of fiscal policy on income inequality in Africa and Argentina. The results indicate that the personal income tax, wealth tax, and social security contributions reduce income inequality in both. Similarly Muinelo and RocaSagalés (2011) study the impact of fiscal policy on income distribution using unbalanced panel data from 1972 to 2006 of middle and upper middle income countries. The results indicate that higher direct taxes and current government expenditures reduce income inequality.

Alavoutunki et al. (2017) study the impact of indirect taxes on income inequality in developing countries. The results of country fixed effect regressions and instrumental variable analysis show that the introduction of VAT has increased the income inequality while it has no effect on the consumption based inequality. Similarly Rehman and Nasir (2019) study the incidence of indirect taxes in Pakistan, concluding that the 
incidence of GST falls unevenly on low income groups. They also find that imposing uniform GSTs can have a negative impact on health outcomes especially on child health (less than 5 years). Many empirical studies such as Jamal and Javed (2013), Rafaqat (2008) and Rafaqat and Hasan (2005) find the overall incidence and burden of Pakistan's GST on household welfare. They used various issues of the Household Integrated Economic Survey (HIES) data. The results of these studies confirm the regressivity of GST on food products, clothing, and utilities while on durable items and petroleum products, it appeared to be progressive.

Sivashanka et al. (2017) study the impact of changes in the rate of the VAT on the Gini coefficient and Theil Index of Sri Lanka. The results show that the revision of the VAT had no significant impact on inequality. Using the Kakwani progressivity index, their results show that, due to the exemption of food items and other necessary goods from VAT, the tax system is relatively progressive. Adukonu and Grace's (2016) study of Ghana finds that increases in the indirect taxes increase poverty via the agriculture sector as the Ghanaian economy is mostly agrarian.

Overall there is consensus in the literature that direct taxes and expenditure policies reduce the income inequality while the indirect taxes are relatively regressive and have negative effects on low income households.

\section{Theoretical Framework and Methodology}

\subsection{Theoretical Framework}

There is extensive theoretical literature on the effectiveness of fiscal policy on income inequality. However, there is less empirical research on the issue especially for the developing countries. However, the importance of fiscal policy has regained its importance as a result of the work of Piketty (2015). The effect of fiscal policy on income inequality has recently gained momentum (Clifton et al., 2020; Lustig, 2016; Martorano, 2018). Applying the Kneller et al. (1999) and Muinelo and Roca-Sagales (2011) framework to the modelling of the impact of fiscal variables on inequality in Pakistan in period $t$ will be the function of a set of fiscal variables (FV) and non-fiscal variables (NFV). The Gini coefficient (GI) is used for income inequality. So we can write the model as;

$$
G I_{t}=\alpha+\beta \sum_{i}^{m} F V_{t}+\gamma \sum_{i}^{h} N F V_{t}+\mu_{t}
$$


Where $\sum_{t}^{m} F V_{t}$ and $\sum_{i}^{h} N F V_{t}$ represent fiscal and non-fiscal conditioning variables. $G I_{t}$ is the gini coefficient index.

Assuming that the vector $F V$ includes all the relevant variables of a budget constraint, then we can deduce that:

$$
\sum_{t}^{m} F V_{t}=0
$$

In order to estimate equation (1), one element of the budget constraint must be excluded in order to avoid perfect collinearity. First we can rewrite the equation (1) as:

$$
G I_{t}=\alpha+\sum_{i}^{m} \beta_{i} F V_{t}+\beta_{m} F V_{m t}+\sum_{i}^{h} \gamma_{i} N F V_{t}+\mu_{t}
$$

Now we can omit the $F V_{m t}$ variable in order to avoid multicollinearity. Then the identity $\sum_{i}^{m} F V_{t}=0$ implies that the equation actually estimated is;

$$
G I_{t}=\alpha+\sum_{i}^{h-m}\left(\beta_{i}-\beta_{m}\right) F V_{t}+\sum_{i}^{h} \gamma_{i} N F V_{t}+\mu_{t}
$$

In equation (4), instead of testing the zero coefficient of $F V_{t}\left(\beta_{i}=0\right)$ as the null hypothesis, we test $\beta_{i}-\beta_{m}=0$. So the interpretation of each estimated coefficient of the fiscal variables is the effect of a unitary change in the model's independent variable offset by a unitary change in the excluded fiscal variable, which is an implicit financing element. If the excluded fiscal variable is changed then the estimated coefficients of the included fiscal variables will also change. In this study, the vector of fiscal variables include: direct taxes (DTR), indirect taxes (ITR), and non-tax revenues (NTR), government fiscal deficit/surplus (GFD), current expenditures (CE), development expenditures (DE) and social expenditures (SE). In a simple linear model, inequality, as measured by the Gini index, and putting the relevant included fiscal variables in our model, will be as follows:

$$
\begin{aligned}
G I_{t}= & \alpha+\beta_{1} D T R_{t}+\beta_{2} I T R_{t}+\beta_{3} N T R_{t}+\beta_{4} G F D_{t}-\beta_{5} C E_{t}- \\
& \beta_{6} D E_{t}-\beta_{7} S E_{t}+\gamma \sum_{i}^{h} N F V_{t}+\mu_{t}
\end{aligned}
$$

Following Kneller et al. (1999), Muinelo and Roca-Sagales (2011), and Acosta and Morozumi (2017), one of the fiscal variables has to be dropped from the regression model. We will exclude social expenditures due to multicollinearity, as the current and development expenditures include social spending as well. However, the interpretation of each estimated coefficient of the fiscal variables is the effect of a unitary change in the 
model independent variable offset by a unitary change in the excluded fiscal variable (in this case SE). In other words the estimated coefficients of direct taxes would be interpreted as representing the net effect on the Gini index of an increase in direct taxes used to finance an increase in other expenditures, i.e. $\left(\beta_{1}-\beta_{7}\right)$.

Moreover, the set of non-fiscal variables include per capita income, average gross school enrollment as the proxy of human capital, and the liberty index are used as control variables.

\subsection{Data and Empirical Methodology}

The Gini index, a statistical measurement of income inequality, is our dependent variable. In case of perfect equality in a society, the lowest 20 percent of people earn 20 percent of total income. Its values range between 0 and 1 indicating perfectly equality and perfect inequality, respectively (Lambert \& Aronson, 1993; Milligan, 2013). The data for the Gini index is taken from the Standardized World Income Inequality Database (2020). It uses the net income, i.e. after taxes and transfer income, for measurement of the Gini index. This database is the most commonly used for inequality, because it uses various imputation techniques to fill in missing values, and also standardizes the data for all countries, taking the World Income Inequality Database (WIID) as the starting point. Another reason for using Gini coefficient rather than other index of inequality is that it offers the broadest coverage across time (Solt, 2020).

The tax to GDP ratio is our first main fiscal variable. It is an aggregate of all tax revenues comprising direct taxes such as the income tax, wealth tax, corporate tax, and withholding tax while indirect tax revenues include GST, excise, and custom duties, etc. The data on taxation are obtained from the 2017 edition of government revenue dataset (GRD). This dataset provides disaggregated data on tax revenues that helps to analyze the effect of tax composition on the Gini index (Prichard et al., 2014). To ascertain the heterogeneous effects from different taxes, in an alternative specification, we replace total taxes with direct taxes and indirect taxes, respectively. The direct taxes are expected to more equalize the income by redistributing the income from rich to poor, while the indirect tax revenues are regressive in nature and leave income distribution deteriorated (Martorano, 2018; Tsounta \& Osueke, 2014).

Non-tax revenues also help government to finance various government expenditures. These non-tax revenue includes profits of public 
enterprises such the Pakistan Telecommunication Authority (PTA), State Bank of Pakistan, royalties on gas and oil and other dividends of public enterprises, selling of government properties, and privatization. The non-tax revenues have an ambiguous effect on the income inequality. If non-tax revenues are used as social and pro-poor physical infrastructure then it will ameliorate the income distribution and vice versa. The data on non-tax revenues are taken from the various issues of economic surveys of Pakistan.

The third fiscal variable is the government's overall fiscal surplus or deficit. It is the total revenues minus total government outlays. Most countries maintain various degrees of fiscal deficit typically bridged by external and internal loans. The data on fiscal deficits are taken from the various issues of the economic survey of Pakistan. It is shown that during fiscal consolidations, income inequality usually rises and it falls during fiscal profligacy. Fiscal consolidations are often carried out by reducing subsidies and transfers, which principally affect the low income households (Agnello \& Sousa, 2014).

Current public and development expenditures are also included as fiscal instruments in the model. The current public expenditures include salaries, pension, interest payments, subsidies, grants, and social expenditures, i.e. health and education. Development expenditures include the net acquisition of non-financial assets such building physical infrastructure, public firms, etc. Both current and development expenditures are expected to ameliorate the income distribution. As government expenditures increase economic activity and employment, they increase net income of the people and result in an improved distribution of income. Moreover infrastructure development, especially in underdeveloped areas, connect them to urban areas with additional productive opportunities (Brennenman \& Kerf, 2002; Wolf \& Zacharias, 2007).

Besides fiscal variables, there are a number of other non-fiscal variables that are expected to influence the income distribution. The choice of control variables are based on the previous research on determinants of inequality. The first included control variable in the model is GDP per capita (GDPC). A rise in GDPC may initially increase income disparities but after a certain stage this trend reverses. The reason of increasing inequality is due to shifting of labor from agriculture to industrial sector, and as industrial sector returns are higher than agriculture, the per capita income of people involved in industry rises leading to increase in income inequality. At later stages of development, as more workers enter the industrial sectors and move up in the ladder, income disparities are reduced (Barro, 1999). It is also 
expected that increases in GDP per capita increase the income of the poor, thus equalizing income levels. Moreover, increases in GDP stimulate revenue generation, resulting in increased public investment for inclusive growth and ameliorating the income distribution (Akram \& Hamid, 2016; Dollar \& Kraay, 2001, 2002; Page, 2006).

The second control variable is human capital (HC). The gross enrollment ratio (\%) is the proxy of human capital in this study. It is the average of the gross primary, secondary and tertiary enrollment ratio (\%). Its data is taken from the WDI (2020). HC is a major factor affecting the income distribution in a country as educational attainment embodied in a worker is a main determinant of lifetime earnings. Greater educational equality will ameliorate the income distribution while educational inequality especially in terms of quality differences will deteriorate it (Lee \& Lee, 2018).

The third variable is the civil liberty index (CL). More democratic and pro- public governments are expected to spend more on their population as compared to non-elected governments. Therefore, the civil liberty index is also expected to have an ameliorating effect. On the other hand, high inequality leads to political violence and instability (Acemoglu \& Robinson, 2000). The data of Pakistan's CL is taken from the Freedom House (2020). It covers almost all countries since 1972 through its Freedom in the World Survey. Altogether, we have taken the annual data of Pakistan fiscal and non-fiscal data from 1980 to 2019.

Table 1: Definition of Variables and Sources of Data

\begin{tabular}{lll}
\hline Variable descriptions & \multicolumn{1}{c}{$\begin{array}{c}\text { Unit of } \\
\text { measurement }\end{array}$} & \multicolumn{1}{c}{ Sources } \\
\hline Gini Index, dependent variable & $0-1$ & $\begin{array}{l}\text { Standardized World Income } \\
\text { Inequality Database (SWIID) } \\
(2020)\end{array}$ \\
$\begin{array}{l}\text { Direct Taxes; income, property } \\
\text { and capital gain taxes }\end{array}$ & $\%$ of GDP & $\begin{array}{l}\text { 2015, Government Revenue } \\
\text { Data Set and various issues of } \\
\text { Economic survey of Pakistan }\end{array}$ \\
$\begin{array}{l}\text { Indirect Taxes; taxes on goods } \\
\text { and services, trade etc. }\end{array}$ & $\%$ of GDP & $\begin{array}{l}\text { 2015, Government Revenue } \\
\text { Data Set and Economic } \\
\text { surveys of Pakistan }\end{array}$ \\
$\begin{array}{l}\text { Other Revenue; royalties of } \\
\text { oil/gas, dividends of public } \\
\text { enterprises, selling of } \\
\text { government properties and } \\
\text { privatization }\end{array}$ & $\%$ of GDP & $\begin{array}{l}\text { 2015, Government revenue } \\
\text { Data Set and Economic } \\
\text { surveys of Pakistan }\end{array}$ \\
\hline
\end{tabular}




\begin{tabular}{|c|c|c|}
\hline Variable descriptions & $\begin{array}{c}\begin{array}{c}\text { Unit of } \\
\text { measurement }\end{array} \\
\end{array}$ & Sources \\
\hline $\begin{array}{l}\text { Fiscal Deficit; total expenditures } \\
\text { minus total revenues }\end{array}$ & $\%$ of GDP & Economic surveys of Pakistan \\
\hline $\begin{array}{l}\text { Current Expenditure, social } \\
\text { expense, salary, pension, } \\
\text { subsidy, interest payment etc. }\end{array}$ & $\%$ of GDP & Economic surveys of Pakistan \\
\hline $\begin{array}{l}\text { Development Expenditure; net } \\
\text { acquisition of capital stock, } \\
\text { infrastructure development }\end{array}$ & $\%$ of GDP & Economic surveys of Pakistan \\
\hline GDP per capita & $\begin{array}{l}\text { constant }(2010 \\
\text { US\$) }\end{array}$ & $\begin{array}{l}\text { World Development Indicator } \\
\text { (WDI) }\end{array}$ \\
\hline $\begin{array}{l}\text { Human Capital; average of } \\
\text { gross primary, secondary and } \\
\text { tertiary enrolment ratio }(\%) \text {. }\end{array}$ & $\begin{array}{l}\text { Gross Enrollment } \\
\text { Ratio (\%) }\end{array}$ & WDI (2020) \\
\hline $\begin{array}{l}\text { Civil Liberty; freedom of } \\
\text { expression and association, rule } \\
\text { of law, individual rights and } \\
\text { personal freedom }\end{array}$ & $\begin{array}{l}\text { It ranges from } 1 \\
\text { (full freedom) to } 7 \\
\text { (no freedom) }\end{array}$ & Freedman House (2020) \\
\hline
\end{tabular}

\subsection{Econometric Model}

This section summarizes briefly Autoregressive Distributed Lag (ARDL) Model, also known as bounds testing approach. This approach is used to find the presence of short and long run relationships between the Gini index and fiscal and non-fiscal variables in Pakistan. In order to avoid spurious regressions, an Augmented Dicky Fuller Test is carried out. At the beginning, the unit root is used for all variables at level form, then their first difference and so on until the null hypothesis of a unit root is rejected. The results of the ADF test in Table 2 suggest that some variables are I(0) and others are I(1). In that case, the most suitable method for estimation is ARDL co-integration model suggested by (Pesaran et al., 2001). There are a number of advantages of the ARDL technique. Firstly, it allows modelling series integrated of different orders but not more than one. Secondly, as compared to other methods, this technique offers a more efficient approach for obtaining the best unbiased estimates of the long-run as well as the short-run relationships. Thirdly, this approach is considered more efficient in small sample size as most developing countries have the problem of data availability (Duarte et al., 2017). So we can write the general equation of an ARDL model for the Gini index as a function of fiscal and non-fiscal variables in the following way.

$$
\begin{array}{rlr}
\Delta G I_{t}= & \alpha+\quad \sum_{i=0}^{n} \alpha_{j} G I_{t-1}+ & \sum_{i=0}^{p n} \beta_{j} F V_{t-1}+\sum_{i=0}^{p n} \gamma_{j} N F V_{t-1} \\
& +\omega E C M_{t-1}+u_{t} & \ldots(6)
\end{array}
$$


Equation (6) denotes the speed of adjustment parameter and statistically significant error correction model (ECM), which must be negative. Moreover, $E C M_{t-1}$ shows the residual obtained from the estimated co-integration model. If there is no co-integration, the error term reduces to zero and we only estimate the short-run ARDL (Pesaran et al., 2001).

$$
\begin{aligned}
\Delta G I_{t}= & \alpha+\sum_{i=0}^{n} \alpha_{j} G I_{t-1}+\sum_{i=0}^{p n} \beta_{j} F V_{t-1}+\sum_{i=0}^{p n} \gamma_{j} N F V_{t-1}+ \\
& \Delta \sum_{i=0}^{p n} \theta_{j} F V_{t-1}+\Delta \sum_{i=0}^{p n} \vartheta_{j} N F V_{t-1}+\omega E C M_{t-1}+u_{t}
\end{aligned}
$$

Where $\alpha_{0}$ and $u_{t}$ denotes intercept and error term respectively. $\alpha_{j}, \beta_{j}$ and $\gamma_{j}$ are the long-run coefficients while $\theta_{j}$ and $\vartheta_{j}$ are the short-run dynamic coefficients.

There are two steps in the ARDL approach. In the first step, we see whether there is co-integration between the variables through the bounds test (Peseran, et al., 2001). So our null hypothesis of no co-integration between the Gini index and other independent variables would be: $\mathrm{H}_{0}=\alpha_{j}=\beta_{j}=\gamma_{j}=$ 0 while the alternative hypothesis is: $\mathrm{H}_{1}=\alpha_{j} \neq \beta_{j} \neq \gamma_{j} \neq 0$ of co-integration among the variables. According to Peseran et al. (2001), the bounds testing approach has two sets of critical values: if $F_{c a l}>F_{u}$ then the null hypothesis of no co-integration $\alpha_{j}=\beta_{j}=\gamma_{j}=0$ is rejected. If $F_{c a l}<F_{l}$, then the hypothesis of no co-integration $\alpha_{j}=\beta_{j}=\gamma_{j}=0$ among the variables is accepted. Lastly, if the computed values lie between the lower and upper critical values, the results are inconclusive.

\section{Results and Discussion}

\subsection{Results of the Unit Root Test}

Before applying the ARDL model, it is required to check the stationarity of all variables. The Augmented Dicky Fuller (ADF) test is used to check the unit root or stationarity of each variable. The bounds testing necessitates that each variable either be in level stationary or integrated of order I(1). Moreover, the bounds test leads to spurious results if one or more than one variables are integrated of order I(2).

Table 2 reports the unit root test results at 1\% and 5\% levels of significance. None of our variables are I(2). The civil liberty index and total tax to GDP ratio are stationary at the $1 \%$ and $5 \%$ levels of significance. The remaining variables are non-stationary with and without trends in their level form. However, they become stationary after taking the first differences at 
the $1 \%$ level of significance. Since our variables are a combination of $\mathrm{I}(0)$ and I(1), the suitable econometric method is the ARDL model.

Table 2: Augmented Dicky Fuller (ADF) Test Results (1985-2019)

\begin{tabular}{|c|c|c|c|c|}
\hline \multirow[t]{2}{*}{ Variables } & \multicolumn{2}{|c|}{ ADF Test Statistics } & \multirow[t]{2}{*}{$1 \%$} & \multirow[t]{2}{*}{$5 \%$} \\
\hline & Level & $1^{\text {st }}$ difference & & \\
\hline GI & -1.382 & $-5.193^{*}$ & $\mathrm{I}(1)$ & $\mathrm{I}(1)$ \\
\hline TTR & $-2.844^{* *}$ & & & $\mathrm{I}(0)$ \\
\hline DTR & -0.725 & $-4.666^{*}$ & $\mathrm{I}(1)$ & $\mathrm{I}(1)$ \\
\hline ITR & -1.994 & $-5.633^{*}$ & $\mathrm{I}(1)$ & $\mathrm{I}(1)$ \\
\hline NTR & -1.017 & $-3.433^{*}$ & $\mathrm{I}(1)$ & $\mathrm{I}(1)$ \\
\hline GFD & -2.067 & $-4.005^{*}$ & $\mathrm{I}(1)$ & $\mathrm{I}(1)$ \\
\hline $\mathrm{CE}$ & -1.768 & $-4.534^{*}$ & $\mathrm{I}(1)$ & $\mathrm{I}(1)$ \\
\hline $\mathrm{DE}$ & -1.672 & $-4.966^{*}$ & $\mathrm{I}(1)$ & $\mathrm{I}(1)$ \\
\hline GDPC & -1.392 & $-3.779^{*}$ & $\mathrm{I}(1)$ & $\mathrm{I}(1)$ \\
\hline $\mathrm{HC}$ & -0.343 & $-3.210^{*}$ & $\mathrm{I}(1)$ & $\mathrm{I}(1)$ \\
\hline CL & $-4.022^{*}$ & & $\mathrm{I}(0)$ & $\mathrm{I}(0)$ \\
\hline
\end{tabular}

Note: the null hypothesis is that the series has unit root. The acceptance of the null hypothesis means that the series is non-stationary. ${ }^{*}$, and ${ }^{*}$ indicate significance at $1 \%$ and $5 \%$ levels respectively. All variables are in $\log$ form.

\subsection{Bound Test for Co-Integration}

In order to check the long-run associations among the variables, we use the bounds test developed by Pesaran et al. (2001). The optimal lag value of variables are obtained through the AIC criterion. The results of the bounds test suggest that the calculated value of F statistics for all three models are greater than the upper bound values, showing a long-run relationship among the variables.

Table 3: Results of Bound Test

\begin{tabular}{|c|c|c|c|c|c|c|}
\hline \multicolumn{3}{|c|}{ Calculated F Statistics } & \multicolumn{4}{|c|}{ Critical F Statistics } \\
\hline Mode & 1 Mode & Model 3 & $\begin{array}{l}\text { Critical } \\
\text { Values }\end{array}$ & $\begin{array}{c}\text { Lower Bound } \\
\text { Value }\end{array}$ & $\begin{array}{c}\text { Upper bound } \\
\text { Value }\end{array}$ & Conclusion \\
\hline \multirow[t]{3}{*}{3.32} & 7.26 & 9.28 & $1 \%$ & 1.95 & 3.06 & Co-integration \\
\hline & & & $2.5 \%$ & 2.22 & 3.39 & holds in all \\
\hline & & & $5 \%$ & 2.48 & 3.70 & models \\
\hline
\end{tabular}

\subsection{Long Run Elasticities for the Inequality}

Table 4 presents the main long-run results of all three models. Model 1 incorporates direct taxes with other fiscal and non-fiscal variables. The results show that direct taxes have a negative effect on income inequality though it is not statistically significant. The insignificant effect of the direct 
taxes might be attributed to the low level of direct taxes in the total tax revenues of Pakistan. However, the indirect taxes and total taxes have a positive and significant effect on the Gini index. In other words the indirect taxes have increased income disparity in the country. The results show that a 1 percent increase in the indirect and total taxes increase the Gini index by 0.076 and 0.069 percent respectively. Similarly, the total tax to GDP ratio has a significantly positive effect on the Gini index. The results indicate that with a 1 percent increase in the total tax to GDP ratio, the Gini index increases by 0.023 percent. As the major portion of tax revenues are indirect taxes and empirical studies also show that the indirect taxes are regressive in nature, low income households mostly bear the burden of indirect taxes (Adukonu \& Grace, 2016; Muinelo \& Roca-Sagalés, 2011). The non-tax revenues havea statistically positive effect on the Gini index. The results indicate that with a 1 percent increase in non-tax revenue, the Gini index increased by 0.005 to 0.007 percent respectively in the model. This result is contrary to other empirical findings. That the coefficients are very small is likely attributable to the meager contribution of non-tax revenues to the total revenues collected in Pakistan.

Similarly, current expenditures have a negative impact on the Gini index, but they are not statistically significant in any model. However, the development expenditures have a negative and significant effect on the Gini index. A 1 percent increase in development expenditures reduces the Gini index by 0.003 percent on average. As the development expenditures have a positive effect on low income groups, especially infrastructure and other mega projects that create employment opportunities for workers, they have positive effects on income leading to decreases in income disparity. Many empirical studies have also confirmed that development-related expenditures have income ameliorating effects (Brennenman \& Kerf, 2002; Calderón \& Servén, 2014). Rationally, the development related expenditures help underdeveloped areas to be connected with urban areas, allowing access to additional economic activities as well as education and health services.

The fiscal deficit has a statistically positive effect on the Gini index in all three models. The results show that a 1 percent increase in the fiscal deficit increases the Gini index by 0.005 to 0.008 percent on average. It is common for developing countries including Pakistan to consistently experience revenue-expenditure gaps. These gaps are bridged by taking internal and external loans and issuing bonds. Internal loans can crowd out private investment, thus having a negative impact on the general employment level. In the long run, when the government begins to accrue high budget deficits, 
it sells government bonds that are likely purchased by wealthy segments of society. However, the burden of debt financing falls on the whole population. Other recent empirical studies have similarly found that large and persistent fiscal deficits increase the public debt leading to rises in income inequality (Agnello \& Sousa, 2012; Hager, 2014).

The non-fiscal variable GDP per capita has a negative effect on the Gini index and it is highly statistically significant. The increase in the per capita income decreases the Gini index. The results show that with a 1 percent increase in the per capita income, the Gini index decreases by 0.053 to 0.057 percent on average in the long run. The increase in GDP per capita not only increases the income of the poor people but it also stimulates the revenue generation allowing government to increase public investment for inclusive growth. Moreover, when there is rapid economic growth, resources can be redistributed from the wealthy to poorer people by imposing taxes thereby reducing the income inequality (Dollar \& Kraay, 2001; Page, 2006).

Human capital measured by the average years of schooling has a significantly positive effect on the Gini index in all three models. The results indicates that a 1 percent increase in human capital increases the Gini index by 0.065 to 0.076 percent on average. This likely occurs due to the 'composition' effect, where inequality rises due to increases in the educational level being limited to a small segment of the population. As education is a major determinant of pay, a rapid increase in education for a relatively small proportion of the population also increases income disparities (Knight \& Sabot, 1983; Li et al., 1998; Muinelo-Gallo \& RocaSagalés, 2011).

The civil liberty index and Gini index have a negative relationship in all three models. The findings show that a 1 percent increase in the civil liberty index decreases income inequality in the country by 0.007 to 0.016 percent on average. If there is freedom and people are given their democratic rights across the board irrespective of their ethnic or geographic location, then the inequality of income will tend to decline in that society (Li et al., 1998; Li \& Zou, 1998). 
Table 4: Long- Run Results of ARDL Model

\begin{tabular}{lccc}
\hline Regressors & Direct taxes (1) & Indirect taxes (2) & Total Taxes (3) \\
\hline $\ln D T R_{t}$ & -0.004 & & \\
$\ln I T R_{t}$ & $(0.005)$ & $0.018^{* * *}$ & \\
& & $(0.004)$ & $0.023^{* * *}$ \\
$\ln T T R_{t}$ & & & $(.0052692)$ \\
& & & $.007^{* * *}$ \\
$\ln N T R_{t}$ & & $0.005^{* * *}$ & $(.002)$ \\
& -0.004 & $(.002)$ & .0001 \\
$\ln C E_{t}$ & $(0.001)$ & -.001 & $(0.005)$ \\
& $(-0.003)$ & $(.005)$ & $-0.003^{* *}$ \\
$\ln D E_{t}$ & $(.010)$ & -0.003 & $(0.001)$ \\
& 0.004 & $(0.001)$ & $0.007^{* * *}$ \\
$\ln G F D_{t}$ & $(0.003)$ & $0.008^{* * *}$ & $(0.002)$ \\
& $0.005^{*}$ & $(.001)$ & $-0.057^{* * *}$ \\
$\ln \left(G D P C_{t}\right)$ & $(0.003)$ & $-0.055^{* * *}$ & $(0.015)$ \\
& $-0.053^{* *}$ & $(0.016)$ & $0.069^{* * *}$ \\
$\ln H C_{t}$ & $(0.025)$ & $0.076^{* * *}$ & $(0.014)$ \\
& $0.065^{* *}$ & $(0.015)$ & $-0.016^{* * *}$ \\
$\ln C L_{t}$ & $(0.027)$ & $-0.011^{* * *}$ & $(0.004)$ \\
& $(-0.007)$ & $(0.004)$ & $2.726^{* * *}$ \\
$\operatorname{Constant}$ & $(0.006)$ & $2.851^{* * *}$ & $(0.399)$ \\
\hline
\end{tabular}

Note: ${ }^{* * *},{ }^{* *}$, and ${ }^{*}$ indicate significant at $1 \%, 5 \%$ and $10 \%$ levels respectively. Standard errors are reported in parentheses. All variables are in log form.

\subsection{Short Run Elasticities for the Inequality}

The short run results of all three model are presented in Table 5. Indirect and total taxes, current and development expenditures, and the civil liberty index have no effect on the Gini index in the short run. In other words, the coefficients on taxes and current expenditures including development expenditure are effectively zero. Therefore these are excluded. However in the short run, direct taxes have increased the Gini index. The results show that, in the short run, a 1 percent increase in the direct tax to GDP ratio leads to the Gini index increasing by 0.007 percent. In the short run, non-tax revenues have a negative effect on the Gini index. Every 1 percent increase in non-tax revenues decreases the Gini index by 0.003 to 0.004 percent on average. Similarly the fiscal deficit has also income ameliorating effect in the short run. The results show that a 1 percent increase in the fiscal deficit decreases the Gini index by 0.003 to 0.005 percent on average. This is because increasing fiscal deficit is an expansionary policy in the short run and will increase general income 
levels, thus decreasing the income inequality in the country (Romer \& Romer, 2010).

Table 5: Short Run Results of ARDL Model

\begin{tabular}{lccc}
\hline Regressors & Direct taxes & Indirect taxes & Total Taxes \\
\hline$\Delta \ln D T_{t}$ & $0.007^{* *}$ & & \\
& $(0.077)$ & $-0.003^{*}$ & $-0.004^{* * *}$ \\
$\Delta \ln N T R_{t}$ & & $(0.001)$ & $(0.002)$ \\
& & $-0.004^{* * *}$ & $-0.003^{* * *}$ \\
$\ln G F D_{t}$ & $-0.004^{* * *}$ & $(0.001)$ & $(0.001)$ \\
& $(0.001)$ & $0.032^{*}$ & $0.044^{* * *}$ \\
$\ln \left(G D P C_{t}\right)$ & Omitted & $(.018)$ & $(0.017)$ \\
& & $0.006^{* *}$ & $0.005^{* *}$ \\
$\ln C L_{t}$ & Omitted & $(0.003)$ & $(0.002)$ \\
& & $-0.789^{* * *}$ & $-0.751^{* * *}$ \\
$E C M_{t-1}$ & $-0.515^{* * *}$ & $(0.122)$ & 0.108 \\
& $(0.138)$ & 0.620 & 0.6855 \\
Adj R-squared & 0.441 & 208.723 & 212.275 \\
Log likelihood & 199.044 & 0.974 & 0.224 \\
Serial Correlation Test & 0.013 & 40 & 40 \\
No of Observation & 40 & & \\
\hline
\end{tabular}

Note: ${ }^{* * *},{ }^{* *}$, and ${ }^{*}$ indicate significant at $1 \%, 5 \%$ and $10 \%$ levels respectively. Standard errors are reported in parentheses. All variables are in log form.

Per capita income has a positive effect on the Gini index in models 2 and 3 . The results indicate that, for a 1 percent increase in the per capita income, the Gini index increases by 0.032 to 0.044 percent on average. In the short run, the increase in real income will increase the income inequality thus validating the Kuznet curve. Similarly, the civil liberty index also has a positive effect on the Gini coefficient in contrast to other empirical studies, although the coefficient size is negligible.

Lastly, the ECM coefficient is significant, negative, and less than one. The value of speed of adjustment ranges from -0.515 to -0.751 indicating a moderate adjustment process. We interpret this to mean that the change in the Gini index from the short run to long run is corrected by approximately 51 percent to 75 percent each year. It means that any shock causes disequilibrium in the system will take 1.5 to two years to achieve the equilibrium again. Moreover, the cumulative sum (CUSUM) and cumulative sum of square (CUSUMQ) is also used to check the stability of the parameters in the model. The CUSUMQ tests reveal the stability of the ARDL procedure. Models 1-3 in Appendix 2-4 show that the CUSUMQ lines are lying in between the critical bound of the 5 percent level of 
significance over the sample period, indicating all coefficients in the ECM models are stable.

\section{Conclusion}

Due to rises in income inequality around the world, fiscal policy has again come into the limelight as an effective tool for redistribution. Moreover, empirical studies also have associated the unequal distribution of income with social injustice, political unrest, and negative impacts on growth. Fiscal policy affects aggregate demand, production of goods and services and also serves as an effective tool for income distribution. However, most of the empirical studies have focused on the effect of fiscal policy on economic activity. There is a relative dearth of empirical studies on the impact of fiscal policy on income distribution.

This study has investigated the impact of various fiscal policy instruments on income inequality in Pakistan. The results of our empirical study suggest that direct taxes reduce income inequality while indirect taxes increase income disparities in the country. As the major share of tax revenues are indirect taxes, the current tax regime of Pakistan is not effectively redistributing income. Indirect taxes are regressive in nature and low income household primarily bear their burden. At the same time, development expenditures have significantly reduced the Gini index, our measure of income inequality. Development expenditures have a positive effect on low income groups, especially infrastructure and other mega projects, by creating employment opportunities and raising income. However, the fiscal deficit has increased the Gini index. In the long run when government enters into high budget deficits, it sells government bonds which are likely purchased by the wealthy. Large and persistent fiscal deficits increase the public debt whose financing burden falls on the whole population, thus increasing the overall inequality. Similarly, human capital has also significantly raised the Gini index in all three of our models. Inequality in educational quality is likely the cause of such an impact of education on income disparities and should be brought to the attention of policymakers. The civil liberty index and Gini index have a strongly negative relationship in all three models. When there is freedom and people are given their democratic rights across the board irrespective of their ethnic or geographic location, then income disparities tend to lessen.

This study suggests that in the case of Pakistan, where direct taxes are low, a large shadow economy exists, and weak tax administration 
prevails, an increase in development expenditures and broadening of the tax base of direct taxes should be the main fiscal policy tools for income redistribution. Moreover, persistent high fiscal deficits in the long run should be avoided. Finally, governments should reduce educational inequalities and promote democratic values in the country in order to promote greater fairness in distribution of income. 


\section{References}

Acemoglu, D., \& Robinson, J.A. (2001). A theory of political transitions. American Economic Review, 91(4), 938-963.

Acosta-Ormaechea, S., \& Morozumi, A. (2017). Public spending reallocations and economic growth across different income levels. Economic Inquiry, 55(1), 98-114.

Adukonu, S. E. F. K. \& Ofori-Abebrese, G. 2016. Relative Impact of Various Taxes on Poverty in Ghana. Mediterranean Journal of Social Sciences, 7(3), 150-150.

Agnello, L., \& Sousa, R.M. (2014). How does fiscal consolidation impact on income inequality?. Review of Income and Wealth, 60(4), 702-726.

Akram, N., \& Hamid, A. (2016). Public Debt, Income Inequality and Macroeconomic Policies: Evidence from South Asian Countries. Pakistan Journal of Social Sciences (PJSS), 36(1), 99-108.

Alavuotunki, K., Haapanen, M., \& Pirttilä, J. (2017). The consequences of the value-added tax on inequality. CESifo Working Paper, No. 6318.

Alesina, A., \& Perotti, R. (1996). Income distribution, political instability, and investment. European economic review, 40(6), 1203-1228.

Bakija, J. (2014). Social Welfare, Redistribution, and the Tradeoff between Efficiency and Equity, with Developing Country Applications: Williams College, Massachusetts, USA

Barro, R.J. (1999). Determinants of democracy. Journal of political Economy, 107(S6), S158-S183.

Benabou, R. (1996). Inequality and growth. NBER macroeconomics annual, 11-74.

Berg, A., Ostry, J.D., Tsangarides, C.G., \& Yakhshilikov, Y. (2018). Redistribution, inequality, and growth: new evidence. Journal of Economic Growth, 23(3), 259-305.

Bhatti, A.A., Batool, Z. \& Naqvi, H.A. (2015). Fiscal policy and its role in reducing income inequality: a CGE analysis for Pakistan. The Pakistan Development Review, 843-862. 
Bird, R.M., \& Zolt, E.M. (2005). The limited role of the personal income tax in developing countries. Journal of Asian Economics, 16(6), 928-946.

Brenneman, A., \& Kerf, M. (2002). Infrastructure \& poverty linkages. A Literature Review", The World Bank, Washington, DC.

Calderón, C., \& Servén, L. (2014). Infrastructure, growth, and inequality: an overview. Policy Research Working Paper 7034, World Bank, Washington, DC

Causa, O. \& Hermansen, M. (2017). The effectiveness of tax and transfer systems in reducing income inequality across OECD countries. Documents de travail du Département des affaires économiques de l'OCDE.

Cevik, M.S. (2016). Unlocking Pakistan's Revenue Potential. International Monetary Fund.

Chandoevwit, W., \& Dahlby, B. (2007). The marginal cost of public funds for excise taxes in Thailand. eJTR, 5(1), 135-176.

Clifton, J., Díaz-Fuentes, D., \& Revuelta, J. (2020). Falling Inequality in Latin America: The Role of Fiscal Policy. Journal of Latin American Studies, 52(2), 317-341.

Cornia, G.A., \& Martorano, B. (2012). Development policies and income inequality in selected developing regions, 1980-2010 (No. 210). United Nations Conference on Trade and Development.

Cyan, M.R., Koumpias, A.M., \& Martinez-Vazquez, J. (2016). The determinants of tax morale in Pakistan. Journal of Asian Economics, 47, 23-34.

De La Croix, D., \& Doepke, M. (2003). Inequality and growth: why differential fertility matters. American Economic Review, 93(4), 10911113.

Dollar, D., \& Kraay, A. (2002). Growth is Good for the Poor. Journal of Economic Growth, 7(3), 195-225.

Duarte, L., Kedong, Y., \& Xuemei, L. (2017). The relationship between FDI, economic growth and financial development in Cabo Verde. International Journal of Economics and Finance, 9(5), 132-142. 
Duncan, D. \& Sabirianova Peter, K. (2012). Unequal inequalities: Do progressive taxes reduce income inequality?

Freedom House (2020). Freedom in the World 2020: A Leaderless Struggle for Democracy. Washington, DC.

Frenette, M., Green, D.A. \& Milligan, K. (2009). Taxes, transfers, and Canadian income inequality. Canadian Public Policy, 35(4), 389-411.

Galor, O., \& Tsiddon, D. (1997). Technological progress, mobility, and economic growth. The American Economic Review, 363-382.

Gonzalez, F.M. (2007). Effective property rights, conflict and growth. Journal of Economic Theory, 137(1), 127-139.

Goñi, E., López, J.H. \& Servén, L. (2008). Fiscal redistribution and income inequality in Latin America, The World Bank.

Hager, S.B. (2014). What happened to the bondholding class? Public debt, power and the top one per cent. New Political Economy, 19(2), 155-182.

Hassan, B., \& Sarker, T. (2012). Reformed general sales tax in Pakistan. International VAT Monitor, 23(6), 417-421.

Hoeller, P., Joumard, I., Bloch, D. \& Pisu, M. (2012). Less income inequality and more growth-are they compatible? Part 1: mapping income inequality across the OECD.

Joshi, A., Prichard, W., \& Heady, C. (2014). Taxing the informal economy: The current state of knowledge and agendas for future research. The Journal of Development Studies, 50(10), 1325-1347.

Kaldor, N. (1963). Taxation for economic development. The Journal of Modern African Studies, 1(1), 7-23.

Karl, T.L. (2000). Economic inequality and democratic instability. Journal of Democracy, 11(1), 149-156.

Khan, F. (2015). Pakistan's self-inflicted economic crises. Pakistan's enduring challenges (pp. 178-202). University of Pennsylvania Press.

Kneller, R., Bleaney, M.F., \& Gemmell, N. (1999). Fiscal policy and growth: evidence from OECD countries. Journal of public economics, 74(2), 171-190. 
Knight, J.B., \& Sabot, R.H. (1983). Educational expansion and the Kuznets effect. The American Economic Review, 73(5), 1132-1136.

Lambert, P.J., \& Aronson, J.R. (1993). Inequality decomposition analysis and the Gini coefficient revisited. The Economic Journal, 103(420), 1221-1227.

Lee, J.W., \& Lee, H. (2018). Human capital and income inequality. Journal of the Asia Pacific Economy, 23(4), 554-583.

Li, H., \& Zou, H.F. (1998). Income inequality is not harmful for growth: theory and evidence. Review of development economics, 2(3), 318-334.

Li, H., Squire, L., \& Zou, H.F. (1998). Explaining international and intertemporal variations in income inequality. The economic journal, 108(446), 26-43.

Lustig, N. (2016). Fiscal policy, inequality and the poor in the developing world. Center for Global Development Working Paper.

Maboshe, M., \& Woolard, I.D. (2018). Revisiting the impact of direct taxes and transfers on poverty and inequality in South Africa (No. 2018/79). WIDER Working Paper.

Martinez-Vazquez, J., Moreno-Dodson, B., \& Vulovic, V. (2012). The Impact of Tax and Expenditure Policies on Income Distribution: Evidence from a large panel of countries. Andrew Young School of Policy Studies Research Paper Series, (12-30).

Martorano, B. (2018). Taxation and inequality in developing countries: lessons from the recent experience of Latin America. Journal of International Development, 30(2), 256-273.

Milligan, K. S. (2013). Income inequality and income taxation in Canada: Trends in the Census 1980-2005. The School of Public Policy Publications, Canada.

Muinelo-Gallo, L., \& Roca-Sagalés, O. (2011). Economic growth and inequality: the role of fiscal policies. Australian Economic Papers, 50(2-3), 74-97.

Naqvi, H.A., Masood, M.T. \& Naeem, R.A. (2011). Impact of structural adjustment programme on household welfare and inequality- 
Pakistan a case-in-point for the developing countries. Management Research, 4(1).

Padda, I. (2010). On Minimizing the Welfare Cost of Fiscal Policy: Pakistan's Case. Pakistan Journal of Applied Economics, 20, 77-99.

Padda, I. U.H. (2014). On minimizing the welfare cost of fiscal policy: evidence from South Asia. Quality E Quantity, 48(3), 1553-1572.

Padda. I, U.H., \& Akram, N. (2009). The impact of tax policies on economic growth: evidence from South-Asian economies. The Pakistan Development Review, 48(4), 961-971.

Page, J. (2006). Strategies for pro-poor growth: pro-poor, pro-growth or both? Journal of African Economies, 15(4), 510-542.

Pakistan, Ministry of Finance. (2017). Pakistan economic survey 2019-20. Available from http://www.finance.gov.pk/survey/chapter_20/ 04_Fiscal_Development.pdf

Papanek, G.F., \& Kyn, O. (1986). The effect on income distribution of development, the growth rate and economic strategy. Journal of Development Economics, 23(1), 55-65.

Pasha, H.A. (2018). Growth and Inequality in Pakistan. Friedrich Ebert Stiftung.

Pesaran, M.H., Shin, Y., \& Smith, R.J. (2001). Bounds testing approaches to the analysis of level relationships. Journal of applied econometrics, 16(3), 289-326.

Pesaran, M.H., Shin, Y., \& Smith, R.J. (2001). Bounds testing approaches to the analysis of level relationships. Journal of applied econometrics, 16(3), 289-326.

Pesaran, M.H., Shin, Y., \& Smith, R.P. (1999). Pooled mean group estimation of dynamic heterogeneous panels. Journal of the american statistical association, 94(446), 621-634.

Piketty, T. (2015). About capital in the twenty-first century. American Economic Review, 105(5), 48-53.

Prichard, W., Cobham, A., \& Goodall, A. (2014). The ICTD government revenue dataset. 
Rehman, F.U., \& Nasir, M. (2018). In the Same Boat, but not Equals: The Heterogeneous Effects of Indirect Taxation on Child Health in Punjab-Pakistan. PDR Working Paper.

Rodriguez, F. (2000). Inequality, economic growth and economic performance. A Background Note for the World Development Report.

Romer, C.D., \& Romer, D.H. (2010). The macroeconomic effects of tax changes: estimates based on a new measure of fiscal shocks. American Economic Review, 100(3), 763-801.

Rossignolo, D. (2017). Taxes, Expenditures, Poverty, and Income Distribution in Argentina. Commitment to Equity Handbook: A Guide to Estimating the Impact of Fiscal Policy on Inequality and Poverty, 1-30.

Saez, E., \& Zucman, G. (2016). Wealth inequality in the United States since 1913: Evidence from capitalized income tax data. The Quarterly Journal of Economics, 131(2), 519-578.

Safdar, F., \& Padda, I.U.H. (2017). Impact of institutions on budget deficit: the case of Pakistan. NUML International Journal of Business $\mathcal{E}$ Management, 12(1), 77-88.

Solt, F. (2020). Measuring income inequality across countries and over time: The standardized world income inequality database. Social Science Quarterly, 101(3), 1183-1199.

Sultana, S., Alqama, S.K., \& Farooq, M. (2013). US Economics Assistance to India \& Pakistan: A Comparative Study. Pakistan Journal of Social Sciences (PJSS), 33(1), 25-35.

Tsounta, M.E., \& Osueke, A. (2014). What is behind Latin America's declining income inequality?. International Monetary Fund.

Wolff, E.N., \& Zacharias, A. (2007). The distributional consequences of government spending and taxation in the US, 1989 and 2000. Review of Income and Wealth. 


\section{Appendices}

\section{Appendix 1: Trend in FBR Fiscal Indicators for the last one Decades}

\begin{tabular}{ccccccccc}
\hline Year & $\begin{array}{c}\text { Fiscal } \\
\text { Deficit }\end{array}$ & $\begin{array}{c}\text { Current } \\
\text { Expenditure }\end{array}$ & $\begin{array}{c}\text { Development } \\
\text { Expenditure }\end{array}$ & $\begin{array}{c}\text { Total } \\
\text { Revenue }\end{array}$ & $\begin{array}{c}\text { Total Tax } \\
\text { Revenue }\end{array}$ & $\begin{array}{c}\text { Direct } \\
\text { Taxes }\end{array}$ & $\begin{array}{c}\text { Indirect } \\
\text { Taxes }\end{array}$ & $\begin{array}{c}\text { Non Tax } \\
\text { Revenue }\end{array}$ \\
2010 & 6.2 & 16 & 4.4 & 14 & 9.9 & 3.6 & 6.3 & 4.1 \\
2011 & 6.5 & 15.9 & 2.8 & 12.3 & 9.3 & 3.4 & 5.7 & 3 \\
2012 & 8.8 & 17.3 & 3.9 & 12.8 & 10.2 & 3.7 & 6.3 & 2.6 \\
2013 & 8.2 & 16.4 & 5.1 & 13.3 & 9.8 & 4.1 & 7.0 & 3.5 \\
2014 & 5.5 & 15.9 & 4.9 & 14.5 & 10.2 & 3.5 & 6.4 & 4.3 \\
2015 & 5.3 & 16.1 & 4.2 & 14.3 & 11 & 3.75 & 5.6 & 3.3 \\
2016 & 4.6 & 16.1 & 4.5 & 15.3 & 12.6 & 4.18 & 6.51 & 2.7 \\
2017 & 5.8 & 16.3 & 5.3 & 15.5 & 12.4 & 4.19 & 6.3 & 3.1 \\
2018 & 6.5 & 16.9 & 4.7 & 15.1 & 12.9 & 4.3 & 6.8 & 2.2 \\
2019 & 9.1 & 18.7 & 3.2 & 12.9 & 11.8 & 4.17 & 5.93 & 1.1 \\
\hline
\end{tabular}

Source: FBR 2019-20: all variables are \% of GDP.

\section{Appendix 2: Model 1}

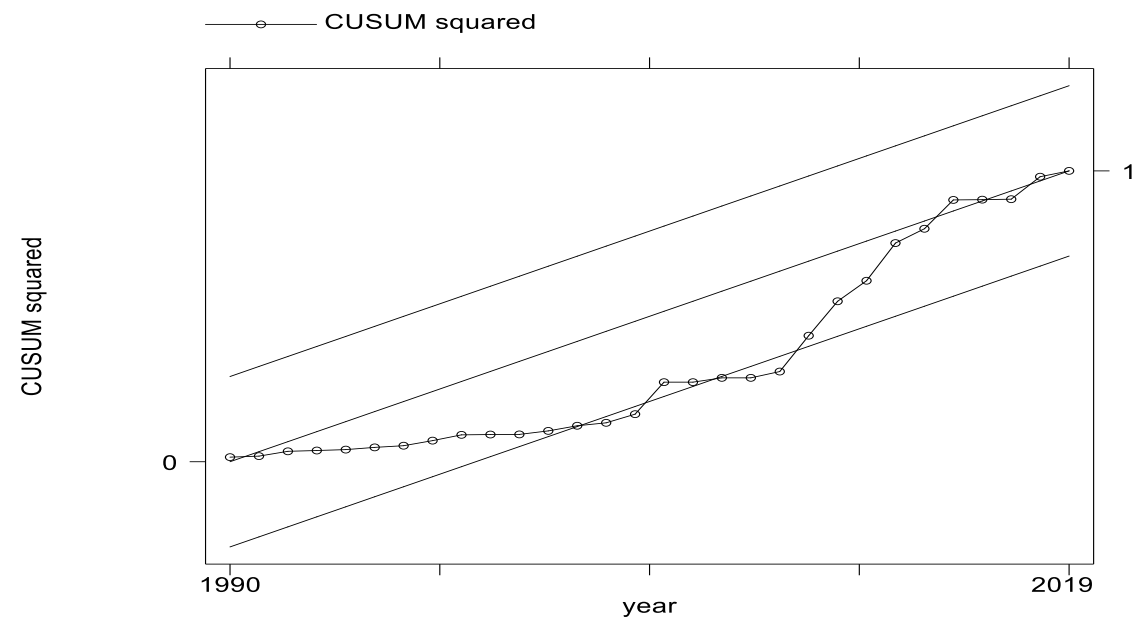


Appendix 3: Model 2

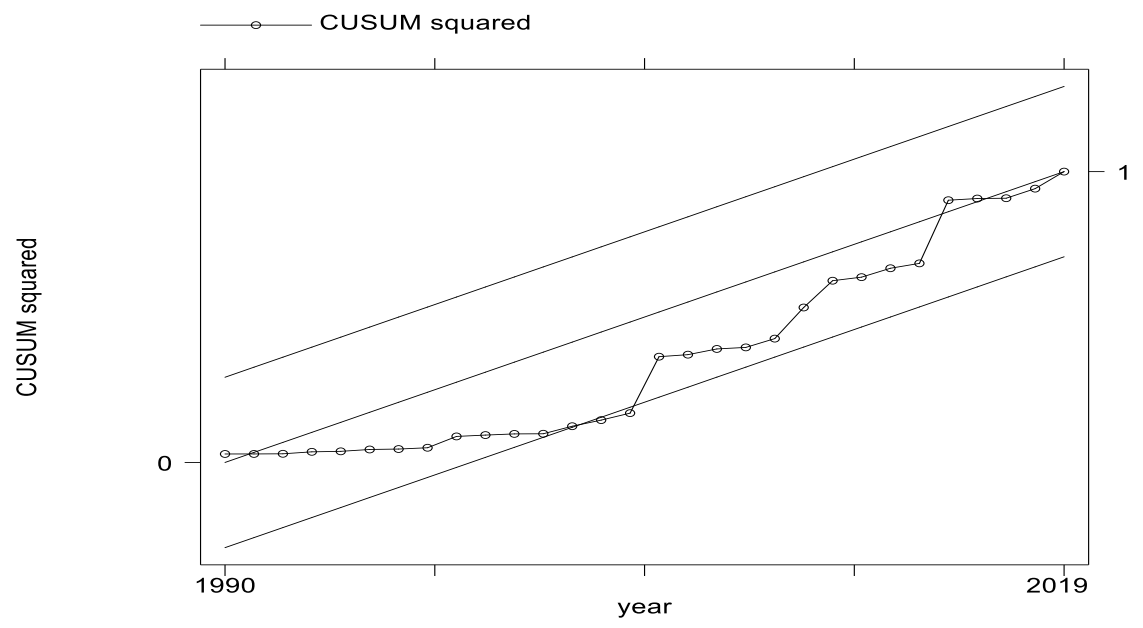

Appendix 4: Model 3

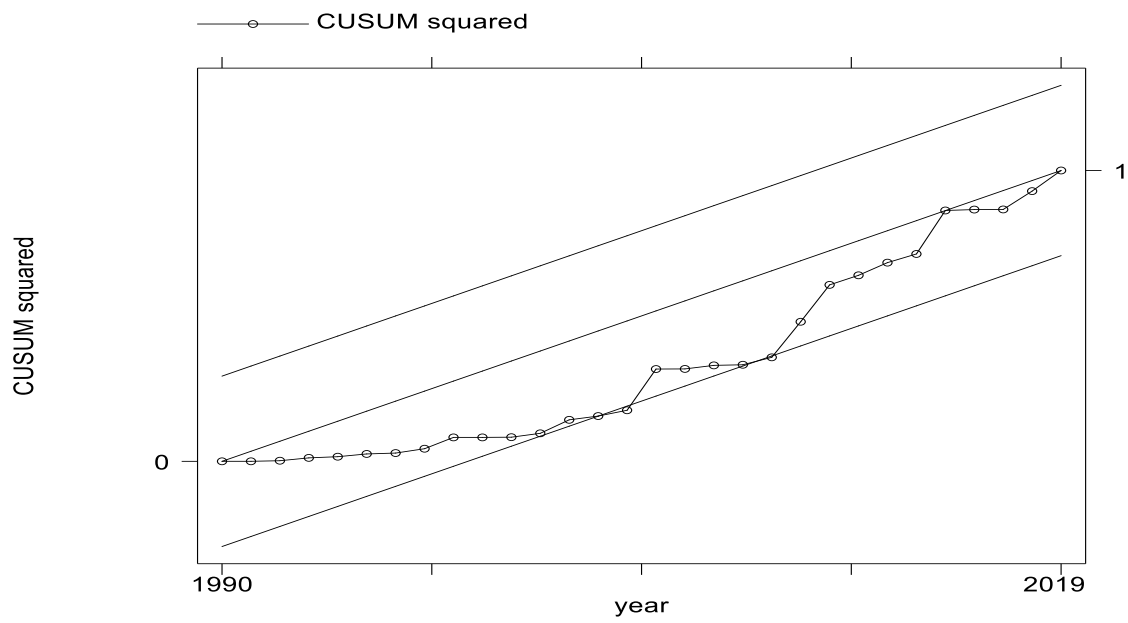

